\title{
Hubungan Sikap dan Norma Subyektif dengan Niat Mengkonsumsi Tablet Suplementasi Besi Pada Ibu Hamil di Banjarmasin
}

\author{
Sudjatmiko Setyobudihono \\ Program Studi Keperawatan STIKES Cahaya Bangsa, Banjarmasin \\ Ermina Istiqomah ${ }^{1}$ \\ Prodi Psikologi Fak. Kedokteran Universitas Lambung Mangkurat, Banjarbaru
}

\begin{abstract}
Compliance with someone who clearly was to have the power of giving orders is part of the existing and evolving behavior among the people of Asia and has not been widely understood in the health program based on the theory of Western countries. The research aims to identify the relationship between attitudes, subjective norms with intent, using data derived from pregnant women were given iron supplementation tablets free of at a health center in Banjarmasin $(N=250)$. Path analysis and structural equation modeling showed that the determinants of subjective norm is a strong determinant for the intention to consume tablets of iron supplementation in pregnant women. Health communication strategy on consumer tablet iron supplementation programs can be increased by taking into account subjective norms prevailing in society.
\end{abstract}

Keywords: Attitudes; Subjective norm; Intention treatment; Iron supplementation.

\begin{abstract}
Abstrak: Praktik pemberian tablet suplementasi zat besi sebagai langkah penanggulangan anemia hamil telah dilaksanakan tetapi terindikasi adanya bukti bahwa ibu hamil tidak memakannya secara kontinyu (Johnson dan Graham, 2011). Kepatuhan pada seseorang yang secara tegas sedang memiliki kekuasaan dalam memberi perintah merupakan bagian dari perilaku yang ada dan berkembang di kalangan masyarakat Asia dan belum banyak di pahami dalam program kesehatan yang berbasis pada teori negara Barat (Chang et al., 2009). Penelitian bertujuan mengidentifikasi hubungan antara sikap, norma subyektif dengan niat, menggunakan data yang berasal dari ibu hamil yang diberikan tablet suplementasi besi secara gratis dari di pusat kesehatan masyarakatdi Banjarmasin $(\mathrm{N}=250)$. Analisis jalur dan structural equation modeling menunjukkan bahwa determinan norma subyektif adalah determinan kuat bagi niat mengkonsumsi tablet suplementasi besi pada ibu hamil. Dengan memperhatikan norma subjektif yang berlaku di masyarakat para penyuluh kesehatan dalam menyusun strategi komunikasi kesehatan yang lebih baik agar konsumsi tablet suplementasi besi dapat meningkat.
\end{abstract}

Kata kunci: Sikap; Norma subyektif; Niat berobat; Suplementasi besi.

Zat besi adalah elemen mikro yang penting bagi berbagai fungsi metabolisme selular. Rata-rata berat zat besi dalam tubuh manusia sehat adalah sekitar $40-50 \mathrm{mg} / \mathrm{kg}$ berat badan, sekitar $75 \%$ ada dalam bentuk erythron sebagai bagian hemoglobin (Yehuda dan Mostofsky, 2010). Anemia didefinisikan sebagai suatu keadaan kadar hemoglobin di dalam darah lebih rendah daripada nilai normal untuk kelompok orang bersangkutan (Lynch, 2011).Anemia gizi besi merupakan kejadian paling sering ditemui di seluruh dunia sebagai akibat kurang gizi pangan dan menjangkiti hampir satu setengah hingga dua milyar orang di seluruh dunia (Lynch, 2011). Wanita hamil secara fisiologis terjadi

\footnotetext{
${ }^{1)}$ Korespondensi tentang artikel ini dapat dialamatkan kepada Sudjatmiko Setyobudihono melalui e-mail: sudjatmikosetyobudihono16@gmail.com; atau kepada Ermina Istiqomahmelalui e-mail: erminaistiqomah06 (a)yahoo.com.
} 
peningkatan kebutuhan zat besi, diperkirakan kebutuhan zat besi harian akan meningkat mulai sekitar $0,8 \mathrm{mg}$ pada trisemester pertama menjadi 4-5 mg selama trisemester kedua dan $>6 \mathrm{mg}$ pada trisemester ketiga (Ramakrishnan, 2001). Penggunaan bentuk tablet dalam program penanggulangan anemia gizi besi masih dipandang sebagai salah satu cara terbaik dan efektif dalam program penanggulangan anemia gizi besi pada ibu hamil (Zhou et al., 2006; Agarwal et al., 2008). Diperkirakan rata-rata temuan anemia kehamilan di Indonesia adalah 50 sampai $70 \%$ dari jumlah ibu hamil (Noronha etal., 2012).

Praktik pemberian tablet suplementasi zat besi sebagai langkah penanggulangan anemia hamil telah dilaksanakan tetapi terindikasi adanya bukti bahwa ibu hamil tidak memakannya secara kontinyu (Johnsondan Graham, 2011). Tingginya klaim pemberian tablet Fe pada ibu hamil tidak diikuti dengan tingginya konsumsi tablet Fe. Persentase ibu hamil yang mendapat tablet tambah darah (TTD) di Provinsi Kalimantan Selatan tercatat $85,4 \%$. Sedangkan persentase ibu yang melaporkan minum tablet $\mathrm{Fe}$ adalah sebagai berikut: lebih dari 90 hari adalah $21,2 \%$, sehingga masih ada cukup besar ibu hamil yang menelan tablet Fe secara tidak teratur, yaitu sebesar 64,2\%. (Kemenkes RI, 2010).

Kurangnya motivasi menjadi penyebab ketidak patuhan proses pengobatan anemia gizi besi pada ibu hamil dengan mengkonsumsi suplementasi besi (de Souza et al., 2009; Bello dan Itiola, 2010; Banhidy et al., 2011), kegagalan program pengobatan anemia dengan suplementasi besi terindikasi akibat rendahnya motivasi dan kurangnya kesadaran akan kegunaannya (Goonewardene et al., 2012). Kepatuhan pada sebuah perintah dapat menjadi salah satu indikator bagi adanya sebuah perilaku tertentu (Baron dan Branscombe, 2012).
Kepatuhan pada seseorang yang secara tegas sedang memiliki kekuasaan dalam memberi perintah merupakan bagian dari perilaku yang ada dan berkembang di kalangan masyarakat Asia dan belum banyak di pahami dalam program kesehatan yang berbasis pada teori negara Barat (Chang et al., 2009). Beberapa individu yang memiliki pengaruh sosial yang telah terbukti mempengaruhi keputusan ibu hamil adalah ibu, suami dan ibu mertua. Pengaruh tersebut masih cukup kuat terutama bagi ibu-ibu di daerah. Pengaruh ibu, suami dan ibu mertua lebih dikarenakan budaya masyarakat yang mewajibkan ibu hamil untuk tunduk dan patuh pada suami, dan orang yang lebih tua. Kedudukan mereka sangat sentral dalam kehidupan seorang ibu hamil dan kejadian tersebut sudah berlangsung turun-temurun (Chang et al., 2009; Park et al., 2010). Seorang ibu hamil akan mendahulukan pendapat atau keputusan mereka sebelum pendapat pribadi (Woodward, 2011).

Studi menunjukkan bahwa adanya hubungan yang signifikan antara sikap, norma subyektif dengan niat seseorang (Kikwilu et al., 2009)terkait dengan perilaku kesehatan yang ditunjukkan (Armitage dan Conner, 2001), implementasi suatu inovasi kesehatan (Jalalian et al., 2010) dan pelaksanaan inisiatif pengobatan tertentu (Dulmen et al., 2007). Studi-studi tersebut menunjukkan adanya hubungan positif antara sikap dan norma subyektif dengan niat untuk melakukan suatu perilaku (Kikwilu et al., 2009).

Sikap adalah respon tertutup seseorang terhadap stimulus atau objek tertentu yang melibatkan faktor pendapat dan emosi yang bersangkutan (senang-tidak senang, setujutidak setuju, baik-buruk dan sebagainya) (Nelsen et al., 2012). Sikap diasumsikan memiliki dua komponen yang bekerja sama: keyakinan tentang konsekuensi dari keyakinan berperilaku dan penilaian positif atau negatif tentang hasil dari masing-masing 
perilaku (Glanz et al., 2008). Studi umumnya menyatakan bahwa sikap seringkali menjadi prediktor yang berpengaruh lebih besar terhadap niat dibandingkan norma subyektif (Fishbein dan Cappella, 2006). Akan tetapi, hasil penelitian tersebut tidak dapat dijadikan dasar bahwa pengujian teori pada suatu negara atau budaya yang berbeda dapat memberikan hasil yang sama. Dengan kata lain, perilaku manusia dapat berbeda antara satu negara dengan negara lainnya karena perbedaan pengaruh sosial dan budaya (Tseng dan Strelzer, 2008).

Norma subjektif sebagai faktor sosial yang menunjukkan tekanan yang dirasakan untuk melakukan atau tidak melakukan perilaku tertentu (Jalalian et al., 2010). Niat adalah tergeraknya hati menuju apa yang dianggapnya sesuai dengan tujuan, baik untuk memperoleh manfaat atau mencegah keburukan. Atau niat adalah suatu kehendak yang dibarengi dengan tindakan, dan niat ini merupakan indikator untuk meluruskan suatu tindakan (Fishbein dan Yzer, 2003). Secara umum, semakin baik sikap dan norma subjektif maka semakin kuat niat (intention) seseorang untuk melakukan perilaku yang dimaksud (Fishbein dan Yzer, 2003; Fishbein dan Cappella, 2006; Jalalian et al., 2010).

Terdapat beberapa studi terkait hubungan antara sikap dan norma subyektif dengan niat berperilaku. Belum terdapat studi yang memberikan pemahaman tentang hubungan antara sikap dan norma subyektif dengan niat ibu hamil dalam mengkonsumsi tablet suplementasi besi di daerah yang memiliki kepatuhan pada seseorang yang secara tegas sedang memiliki kekuasaan dalam memberi perintah.

\section{METODE}

Tujuan dari studi ini adalah menjabarkan hubungan sikap dan norma subyektif terhadap niat ibu hamil dalam mengkonsumsi tablet suplementasi besi.

Ditetapkan 2 hipotesis penelitian yaitu:

- H1 : sikap akan menimbulkan pengaruh positif bagi niat ibu hamil dalam mengkonsumsi tablet suplementasi besi.

- H2 : norma subyektif akan menimbulkan pengaruh positif bagi niat ibu hamil dalam mengkonsumsi tablet suplementasi besi.

\section{Sampel}

Populasi target adalah ibu hamil yang memeriksakan diri di pusat kesehatan masyarakat di wilayah kerja Kota Banjarmasin serta mendapat tablet suplementasi besi secara gratis sebanyak 90 butir. Secara acak terpilih sebanyak 16 pusat kesahatan masyarakat dari 24 pusat kesehatan di seluruh Kota Banjarmasin. Disebarkan secara acak sebanyak 256 kuesioner, tetapi yang sah diikutkan pada uji selanjutnya hanya 250 orang responden $(97,66 \%)$ ibu hamil dengan anemia yang mengkonsumsi suplementasi besi. Alasan tidak sahnya data adalah 6 orang tidak mengisi kuesioner secara lengkap dan tidak dapat menyelesaikan proses penelitian.

\section{Teknik Pengumpulan Data}

Studi ini menggunakan kuesioner untuk semua variabel berdasarkan pada adaptasi beberapa studi terdahulu. Kuesioner sikap dikembangkan untuk mengungkapkan konstruk sikap sebagai faktor prediktif untuk niat yang merupakan variabel keluaran dan merupakan adaptasi dari Fishbein dan Cappella (2006), Ajzen dan Fishbein (2010) dan Jalalian et al. (2010). Conbach's Alpha instrumen sikap adalah $0,818 \quad(>0,6)$. Kuesioner sikap mengungkapkan determinan sikap yaitu variabel keyakinan berperilaku dan evaluasi hasil dari perilaku. Selain itu kuesioner juga mengungkapkan variabel sikap secara keseluruhan atas sebuah perilaku. Kuesioner terdiri dari 12 item pernyataan yang terbagi menjadi 4 item pernyataan 
penilaian variabel sikap secara keseluruhan, 4 item pernyataan variabel keyakinan berperilaku, dan 4 item pernyataan variabel evaluasi keluaran. Keseluruhan item terdiri dari 5 skala Likert mulai dari pernyataan "sangat tidak setuju (1)" hingga "sangat setuju (5)".

Kuesioner dikembangkan untuk mengungkapkan konstruk norma subyektif sebagai faktor prediktif untuk niat yang merupakan variabel keluaran. Kuesioner norma subyektif yang disusun mengungkapkan determinan norma subyektif yaitu: variabel norma subyektif diri sendiri yang mengungkapkan pendapat pribadi mengenai program kesehatan yang dijalankan, dan norma subyektif bagi orang lain yang terdiri dari: variabel keyakinan normatif dan variabel motivasi untuk mencapainya yang mengungkapkan pendapat seseorang mengenai tekanan yang dirasakan untuk melakukan atau tidak melakukan perilaku tertentu. Skala merupakan adaptasi dari Jalalian et al. (2010) yang terdiri dari 10 item pernyataan yang memiliki nilai Cronbach's alpha berkisar antara 0,75-0,93. Kuesioner terdiri dari 10 pernyataan yang terdiri dari: 4 item pernyataan variabel norma subyektif mengukur diri sendiri, 3 item pernyataan variabel keyakinan normatif dan 3 item pernyataan variabel motivasi untuk mencapai, keseluruhan item diukur dengan 5 skala Likert mulai dari pernyataan "sangat tidak setuju (1)" hingga “sangat setuju (5)".

Variabel niat merupakan pernyataan yang menggambarkan tergeraknya hati menuju apa yang dianggapnya sesuai dengan tujuan, baik untuk memperoleh manfaat atau mencegah keburukan. Niat berobat diukur dengan 3 item pernyataan dengan pilihan jawaban metode 5 poin skala Likert, mulai dari sangat tidak berniat (1) hingga sangat berniat (5). Cara ini juga telah digunakan dalam beberapa studi, diantaranya oleh Kikwilu et al. (2009); dan Jalalian et al.
(2010).Cronbach's alpha sebesar 0,844 .

\section{Teknik Analisis Data}

Seluruh data masuk diolah menggunakan bantuan program SPSS for Windows version 18. Tes reliabilitas item menggunakan koefisien korelasi 0,98. Cronbach's alpha digunakan untuk menjamin terdapatnya konsistensi interna pada seluruh variabel. Conbach's Alpha kuesioner sikap adalah 0,818 (>0,6), Cronbach's Alpha kuesioner norma subyekti adalah $0,685(>0,6)$ dan Cronbach's alpha kuesioner niat sebesar $0,844(>0,6)$. Penilaian kelaikan etik studi ini dilakukan oleh Komisi Etik Penelitian LPPM Universitas Airlangga Nomor: 27$1114 / \mathrm{UN} 3.14 / \mathrm{PPd} / 2013$ tanggal 27 September 2013.

\section{HASIL DAN PEMBAHASAN}

\section{Hasil}

Total 256 orang mendapat kuesioner, tetapi hanya 250 orangibu hamil dengan anemia yang mengkonsumsi suplementasi besi yang merespon dan mengisi kuesioner secara lengkap (97,66\%). Rata-rata usia ibu hamil adalah 26,70 tahun (95\% CI : 26,02 27,37), Rata-rata usia ibu saat menikah adalah 21,61 tahun (95\% CI : 21,17 - 22,05). Sebagian besar ibu tidak bekerja $(60,4 \%)$, pendidikan terakhir tamat SMA $(41,2 \%)$ dan berpenghasilan antara 1 juta -2 juta $(56 \%)$.

Analisis tabulasi silang antara variabel sikap dengan variabel niat mengkonsumsi tablet suplementasi besi menujukkan bahwa sebanyak 194 orang $(77,6 \%)$ ibu yang memiliki sikap positif akan memiliki niat mengkonsumsi tablet suplementasi besi yang tinggi. Sebanyak 186 orang $(74,4 \%)$ ibu yang memiliki norma subyektif tinggi akan memiliki niat mengkonsumsi tablet suplementasi besi yang tinggi (Tabel 1 dan Tabel 2). 
Tabel 1. Analisis tabulasi silang sikap dengan niat mengkonsumsi suplementasi besi pada 250 partisipan

\begin{tabular}{llccc}
\hline & & \multicolumn{2}{c}{ niat } & \\
\cline { 3 - 4 } & & rendah & tinggi & Total \\
\hline sikap & negatif & 5 & 8 & 13 \\
& positif & 43 & 194 & 237 \\
Total & & 48 & 202 & 250 \\
\hline
\end{tabular}

Tabel 2. Analisis tabulasi silangnorma subyektif dengan niat mengkonsumsi suplementasi besi pada 250 partisipan

\begin{tabular}{llccc}
\hline & & \multicolumn{2}{c}{ niat } & \\
\cline { 3 - 4 } & & rendah & tinggi & Total \\
\hline normsub & rendah & 7 & 16 & 23 \\
& tinggi & 41 & 186 & 227 \\
Total & & 48 & 202 & 250 \\
\hline
\end{tabular}

Hasil analisis dengan nilai $\alpha=0,05$ menunjukkan bahwa norma subyektif menunjukkan adanya hubungan signifikan terhadap niat ibu hamil dalam mengkonsumsi tablet suplementasi besi $(\mathrm{P}=0,020)$ dengan demikian $\mathrm{H} 2$ diterima atau norma subyektif menimbulkan pengaruh positif bagi niat ibu hamil dalam mengkonsumsi tablet suplementasi besi. Sedangkan sikap tidak menunjukkan adanya hubungan signifikan terhadap niat ibu hamil dalam mengkonsumsi tablet suplementasi besi $(\mathrm{P}=0,995)$ dengan demikian $\mathrm{H} 1$ ditolak atau sikap tidak menimbulkan pengaruh positif bagi niat ibu hamil dalam mengkonsumsi tablet suplementasi besi.

Gambar 2. Hasil analisis hubungan sikap dan norma subyektif dengan niat mengkonsumsi tablet suplementasi besi

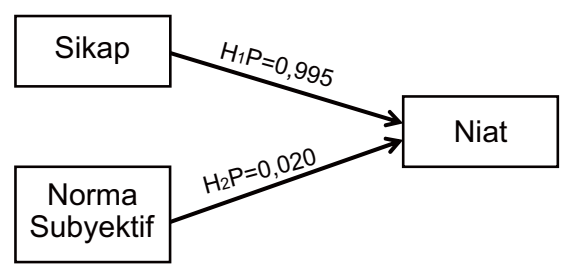

\section{Pembahasan}

Data terkumpul dari $250 \mathrm{ibu}$ hamil yang telah mendapatkan tablet suplementasi secara gratis ketika mereka memeriksakan kehamilannya di pusat kesehatan masyarakat di wilayah kerja Kota Banjarmasin. Tiga variabel yang diteliti memiliki nilai Cronbach's alpha yang tinggi, sehingga mengindikasikan adanya tingkat konsistensi internal dan reliabilitas yang tinggi.

Hasil analisis tabulasi silang memperlihatkan bahwa sikap yang positif dan norma subyektif yang tinggi akan memberikan angka niat yang tinggi. Hal ini menunjukkan bahwa semakin tinggi norma subyektif serta semakin positif sikap yang ditujukkan maka akan mendorong individu tersebut memiliki niat yang semakin tinggi. Dengan demikian pemahaman para penyuluh kesehatan terhadap sikap yang ditunjukkan dan norma subyektif yang dimiliki seseorang akan mendorong timbulnya suatu niat berperilaku yang semakin tinggi.

Hasil analisis hubungan menunjukkan bahwa norma subyektif memiliki nilai signifikan yang lebih baik dibandingkan dengan sikap. Sehingga norma subyektif merupakan determinan bagi suatu niat yang lebih baik dibandingkan dengan sikap. Hasil ini berbeda dengan hasil yang berpendapat bahwa sikap merupakan prediktor yang lebih baik dibandingkan dengan norma subyektif (Fishbein dan Yzer, 2003; Fishbein dan Cappella, 2006). Hasil ini juga menunjukkan bahwa norma subyektif merupakan prediktor timbulnya niat yang lebih baik dibandingkan dengan sikap. Tekanan yang ditunjukkan untuk melakukan atau tidak melakukan perilaku tertentu lebih dapat mendorong seorang ibu hamil untuk terus memiliki niat untuk mengkonsumsi tablet suplementasi besinya.

\section{SIMPULAN DAN SARAN}

Sikap yang positif serta norma subyektif yang tinggi akan mendorong timbulnya niat berperilaku seorang ibu hamil untuk mengkonsumsi tablet suplementasi besi. Norma subyektif merupakan prediktor yang 
lebih baik bagi timbulnya niat seorang ibu untuk mengkonsumsi tablet suplementasi besi.

Diperlukan pemahaman lebih mendalam terhadap faktor-faktor yang dapat meningkatkan nilai norma subyektifitas.
Adanya budaya patuh pada seseorang yang secara tegas sedang memiliki kekuasaan dalam memberi perintah pada seorang ibu hamil merupakan faktor yang harus mendapat perhatian bagi studi-studi selanjutnya.

\section{Daftar Pustaka}

Agarwal, T., Kochar, G.K.,\& Goel, S. (2008). Impact of iron supplementation on anemia during pregnancy. Ethno-Medicine, 2, 149151.

Armitage, C.J. \& Conner, M. (2001). Efficacy of the theory of planned behaviour: a metaanalytic review. British Journal of Social Psychology. 40, 471-499.

Banhidy, F., Acs, N., Puho, E.H.\& Czeizei, AE. (2011). Iron deficiency anemia: pregnancy outcomes with or without iron supplementation. Nutrition. 27, 65-72.

Baron, R.A. \& Branscombe, N.R. (2012). Social Psychology. $13^{\text {th }}$ Ed. Pearson. Boston.

Bello, S.I. \& Itiola, O.A. (2010). Drug adherence amongst tuberculosis patients in the university of Ilorin Teaching Hospital, Ilorin, Nigeria. African Journal of Pharmacy And Pharmacology. 4 (3), 109114.

Chang, M., Feller, E.,\& Nimmagadda, J. (2009). Barriers to healthcare access in Southeast Asian community of Rhode Island. Medicine and Health, 92 (9), 310-313.

De Souza, A.I., Filho, M.B., Bresant, C. C., Ferreira, L.O.C. \& Figueiroa, J.N. (2009). Adherence and side effect of three ferrous sulfate treatment regiment on anemic pregnant women in clinical trials. Cad. Saude Publica. Rio de Janeiro. 25 (6), 1225-1233.

Dulmen, S.V., Sluijs, E., Dijk, L.V., Ridder, D.D., Heerdink, R. \& Bensing, I. (2007). Patient adherence to medical treatment: a review of reviews. BMC Health Services Research. 7 (55), 1-13.

Fishbein, M. \& Yzer, M.C. (2003). Using theory to design effective health behavior interventions. Communication Theory. 13 (2), 164-183.

Fishbein, M. \& Cappella, J.N. (2006). The role of theory in developing effective health communications. Journal of Communication. 56, 1-17.

Glanz, K., Rimer, B.K. \& Viswanath, K. (2008). Health Behavior and Health Education: Theory, Research, and Practice. $4^{\text {th }}$ Ed. Jossey-Bass. San Fransisco.

Goonewardene, M., Shehata, M.\& Hamad, A. (2012). Anaemia in pregnancy. Best Practice and Research Clinical Obstetrics and Gynaecology. 26, 3-24.

Jalalian, M., Latiff, L., Hassan, S.T.S., Hanachi, P. \& Othman, M. (2010). Development of a questionnaire for assesing factors predicting blood donation among university students: a pilot study. Southeast Asian Journal Tropical Medicine and Public Health. 41 (3), 660-666.

Johnson, W.T.D.\& Graham, D.Y. (2011). Diagnosis and management of iron deficiency anemia in the $21^{\text {st }}$ century. Therapeutic Advances In Gastroenterology.4, 177-184.

Kementerian Kesehatan RI.(2010).Riset Kesehatan Dasar (Riskesdas).Badan Penelitian dan Pengembangan Kesehatan, Jakarta.

Kikwilu, E.N., Frencken, J.E., Mulder, J. \& Masalu, J.R. (2009). Dental practitioner' attitudes, subjective norms and intentions to practice atraumatic restorative treatment (ART) in Tanzania. Journal of Applied Oral Science. 17 (2), 97-102. 
Lynch, S.R. (2011). Why nutritional iron deficiency persists as aworldwide problem. The Journal of Nutrition, 141, 763-767.

Nelsen, A., Trautner, B.W., Petersen, N.J., Gupta, S., Barradas, M.R., Giordano, T.P. \& Naik, A.D. (2012). Development and validation of a measure for intention to adhere to HIV treatment. AIDS Patient Care and STDs. 26 (6), 329-334.

Noronha, J.A., Al Khasawneh, E.; Seshan, V., Ramasubramaniam, S.,\& Raman,S. (2012). Anemia in pregnancyconsequences and challenges: areview of literature. Journal of South Asian Federation of Obstetrics And Gynaecology, $4(1), 64-70$.

Park, Y.S., Kim, B.S.K., Chiang, J.\& Ju Charlene, M. (2010). Acculturation, enculturation, parental adherence to Asian cultural values, parenting styles, and family conflict among Asian American college students. Asian American Journal of Psychology. 1 (1), 6779.
Ramakrishnan, U. (2001). Nutritional Anemias. CRC Press LLC.Boca Raton, Florida

Tseng, W.S.\& Streltzer, J. (2008).Cultural Competence in Health Care. Springer Sciences Business Media. New York.

Woodward, M. (2011) Java, Indonesia And Islam. Springer. New York

Yehuda, S.,\& Mostofsky, D.I. (2010).Iron Deficiency And Overload: From Basic Biology to Clinical Medicine. Humana Press. New York.

Zhou, S.J., Gibson, R.A., Crowther, C.A., Baghurst, P.,\& Makrides, M. (2006). Effect of iron supplementation during pregnancy on the intelligence quotient and behavior of children at 4 year of age: long-term followup of arandomized controlled trial. The American Journal of Clinical Nutrition, 83, 1112-1117. 